\title{
Levels and degradability of crude protein in digestive metabolism and performance of dairy cows
}

\author{
Níveis e degradabilidade da proteína bruta no metabolismo digestivo e \\ desempenho de vacas leiteiras
}

\author{
Bruna Gomes Alves ${ }^{1}$; Cristian Marlon de Magalhães Rodrigues Martins ${ }^{1}$; Dannylo de Oliveira Sousa ${ }^{2}$; \\ Marcos André Arcari ${ }^{1}$; Francisco Palma Rennó ${ }^{1}$; Marcos Veiga Santos ${ }^{1}$ \\ ${ }^{1}$ Universidade de São Paulo, Faculdade de Medicina Veterinária e Zootecnia, Departamento de Nutrição e Produção Animal, Pirassununga - \\ SP, Brazil \\ ${ }^{2}$ Swedish University of Agricultural Sciences, Department of Animal Environment and Health, Vastra Gotaland, Sweden
}

\begin{abstract}
Two experiments were conducted to evaluate the effect of the level and degradability of crude protein $(\mathrm{CP})$ on the digestive metabolism and productive performance of dairy cows. In both experiments, 15 Holstein cows with $585 \pm 40 \mathrm{~kg}$ of body weight were distributed in a Latin square design with five contemporary squares, three periods of 21 days and three treatments. In experiment 1 , treatments consisted of three CP levels $(130,160$ or $180 \mathrm{~g} \mathrm{CP} / \mathrm{kg} \mathrm{DM})$, while in experiment 2 , the treatments consisted of three levels of rumen degradable protein (RDP; 80, 100 or $120 \mathrm{~g} R D P / \mathrm{kg} \mathrm{DM}$ ) in diets with average of $163 \mathrm{~g} \mathrm{CP} / \mathrm{kg}$ DM. Variables evaluated in both experiments were dry matter intake (DMI), total apparent digestibility, milk yield (MY) and composition, ruminal fermentation and $\mathrm{N}$ balance. In experiment 1 , the increase of CP from 130 to 180 linearly increased the organic matter, CP, neutral detergent fiber (NDF) and acid detergent fiber (ADF) intake $(\mathrm{kg})$ and the apparent total digestibility coefficient of DM and CP. In addition, a linear increase of MY, fat corrected milk (FCM) and daily production of fat, protein, lactose, casein and total solids was observed. A linear increase in ruminal ammoniacal nitrogen $\left(\mathrm{NH}_{3}-\mathrm{N}\right)$ concentration and nitrogen excretion in milk, feces and urine was also observed. However, there was no observed effect on SCFA concentration. In experiment 2, the increase of the RDP from 80 to 120 increased the DMI, MY, FCM, milk protein content and digestibility coefficient of the NDF, ADF and ethereal extract. Additionally, there was an increase in $\mathrm{NH}_{3}-\mathrm{N}$ concentration and milk nitrogen excretion. The studies indicated that the increase of $\mathrm{CP}$ content up to $100 \mathrm{~g} \mathrm{RDP} / \mathrm{kg} \mathrm{DM}$ increased the DMI and the productive performance of the cows, but also increased urine $\mathrm{N}$. Thus, it is desirable that the increase of the $\mathrm{CP}$ through the increase of the $\mathrm{RDP}$ is carried out up to $100 \mathrm{~g}$ of $\mathrm{RDP} / \mathrm{kg} \mathrm{DM}$, since there is elimination of nitrogen, decrease of milk yield and decrease of propionic acid in values above that level.
\end{abstract}

Keywords: Digestibility. N balance. Protein. Rumen-degradable protein. Ruminal fermentation.

\section{RESUMO}

Dois experimentos foram realizados com o objetivo de avaliar o efeito do nível e da degradabilidade da proteína bruta (PB) no metabolismo digestivo e no desempenho produtivo de vacas leiteiras. Nos dois experimentos, 15 vacas da raça Holandesa com $585 \pm 40 \mathrm{~kg}$ de peso corporal foram distribuídas em delineamento do tipo quadrado latino com cinco quadrados contemporâneos, sendo três períodos de 21 dias e três tratamentos. No experimento 1, os tratamentos consistiram de três níveis de $\mathrm{PB}(130,160$ ou $180 \mathrm{~g} \mathrm{CP} / \mathrm{kg}$ de MS), enquanto que no experimento 2, os tratamentos consistiram de três níveis de proteína degradável no rúmen (PDR; 80, 100 ou $120 \mathrm{~g}$ de PDR/kg MS) em dietas com média de $163 \mathrm{~g} \mathrm{CP} / \mathrm{kg}$ MS. As variáveis avaliadas nos dois experimentos foram: consumo de matéria seca (CMS), digestibilidade aparente total, produção e composição do leite (PL), fermentação ruminal e balanço de N. No experimento 1, o aumento da PB de 130 para 180 aumentou linearmente o consumo de matéria orgânica, PB, fibra detergente neutro (FDN), fibra em detergente ácido (ADF) (kg) e o aparente coeficiente de digestibilidade total de MS e PB. Além disso, foi observado um aumento linear da PL, leite corrigido para gordura (LCG) e produção diária de gordura, proteína, lactose, caseína e sólidos totais. Também foi observado aumento linear na concentração de nitrogênio amoniacal ruminal $\left(\mathrm{N}_{-} \mathrm{NH}_{3}\right)$ e excreção de nitrogênio no leite, fezes e urina. No entanto, não foi observado efeito na concentração de ácidos graxos de cadeia curta. No experimento 2, o aumento do PDR de 80 para 120 aumentou o CMS, PL, LCG, teor de proteína do 
leite e o coeficiente de digestibilidade do FDN, FDA e extrato etéreo. Além disso, houve aumento na concentração de $\mathrm{N}-\mathrm{NH}_{3}$ e excreção de nitrogênio no leite. Os estudos indicaram que o aumento do teor de PB em até $100 \mathrm{~g} \mathrm{RDP} / \mathrm{kg}$ de MS aumentou o CMS e o desempenho produtivo das vacas, mas também aumentou o $\mathrm{N}$ urinário. Assim, é desejável que o aumento da PB através do aumento da PDR seja realizado até $100 \mathrm{~g}$ de PDR/kg de MS, uma vez que há eliminação de nitrogênio, diminuição da produção de leite e diminuição do ácido propiônico em valores acima desse nível.

Palavras-chave: Digestibilidade. Balanço de N. Proteína. Proteína degradável no rúmen. Fermentação ruminal.

Correspondence to:

Marcos Veiga Santos

Universidade de São Paulo, Faculdade de Medicina Veterinária

e Zootecnia, Departamento de Nutrição e Produção Animal

Av. Duque de Caxias Norte, 225

CEP: 13635-900, Pirassununga - SP, Brazil

e-mail: mveiga@usp.br

Received: March 28, 2020

Approved: August 06, 2020

How to cite: Alves BG, Martins CMMR, Sousa DO, Arcari MA, Rennó FP, Santos MV. Levels and degradability of crude protein in digestive metabolism and performance of dairy cows. Braz J Vet Res Anim Sci. 2020;57(3):e168157. https://doi.org/10.11606/issn.1678-4456.bjvras.2020.168157

\section{Introduction}

When dairy cows are fed unbalanced diets, the dietary protein is not effectively used, generating an excess nitrogen $(\mathrm{N})$ that is excreted in feces and urine and negatively affects the environment and economics of dairy farms (Mutsvangwa et al., 2016). The $\mathrm{N}$ excreted by ruminants can be converted into multiple forms, such as ammonia, $\mathrm{N}_{2} \mathrm{O}$ (a potential greenhouse gas) and nitrate, a water pollutant (Kebreab et al., 2001). Previous studies indicated that increasing CP supply from 16.5 to $18.5 \%$ increased milk yield and milk protein content (Bahrami-Yekdangi et al., 2014; Broderick, 2003) but with loss in efficiency of N use and consequently with greater excretion in the environment (Colmenero \& Broderick, 2006b; Rius et al., 2012). On the other hand, the use of diets with lower levels of $\mathrm{CP}$ or rumen degradable protein (RDP) increases the efficiency of $\mathrm{N}$ and meets the requirements of microbial and metabolizable protein and has no negative effects on milk yield (MY).

Increased $\mathrm{N}$ efficiency and microbial protein synthesis can be achieved by optimizing the RDP: RUP ratio (Kalscheur et al., 2006; Wang et al., 2007), by supplying limiting essential amino acids in diets (Broderick et al., 2009; Lee et al., 2012), and the good level of rumen carbohydrate fermentation, mainly starch. The requirements of amino acids are met by rumen-undegradable protein (RUP) while the increasing rumen starch digestibility may increase microbial protein synthesis due to greater supply of substrates (fermentable carbohydrates) for microorganism growth (Vaz-Pires et al., 2008). The optimization of RDP:RUP ratio determines the quantity and quality of proteins and amino acids available to the cow and, to meet the requirements without excessive $\mathrm{N}$, rations must also be balanced for RUP and RDP.

Corn grain, the main energy source used in ruminant diets, is resistant to bacterial fermentation by the presence of a protein matrix that surrounds the starch granule. Thus, several strategies can be adopted to increase protein and starch ruminal digestibility, such as milling, lamination, flocculation and ensilage (high moisture and rehydrated corn). In addition, rehydrated corn silage increases this digestibility through microbial enzymatic degradation with low cost when compared to the lamination and flocculation processes (Arcari et al., 2016; Vaz-Pires et al., 2008). Considering amino acid requirement, it is possible that RUP sources can promote better productive responses when the forage is sugarcane, since shows an imbalance of nutrients and is usually only supplemented with nonprotein nitrogen (NPN).

So, our hypothesis was that optimum levels of $\mathrm{CP}$ and RDP:RUP optimize the productive performance and $\mathrm{N}$ use efficiency. Thus, the aim of the present study was to evaluate the effect of three dietary CP and RDP levels on digestive metabolism, productive performance and $\mathrm{N}$ use efficiency of cows fed diets based on rehydrated corn and sugarcane silage.

\section{Materials and Methods}

This study was approved by the Ethics Committee on Animal Use of the School of Veterinary Medicine and Animal Science (CEUA/FMVZ/USP - protocol number 2671/2012).

\section{Diets and feeding management}

Two experiments were conducted sequentially to assess changes in crude protein content and subsequently in PDR levels. For both experiments, 15 Holstein cows averaging 150 ( $\pm 60 \mathrm{SD}$ ) DIM (days in milk), body weight (BW) of 585 ( $\pm 40 \mathrm{SD}) \mathrm{kg}$ and MY of $30( \pm 4.13 \mathrm{SD}) \mathrm{kg} /$ day were used. The cows were milked twice a day (07:00 
and 16:00) and the intake control was performed daily. The facilities were individual pens of approximately $16 \mathrm{~m}^{2}$. Five $3 \times 3$ contemporary Latin square was used as experimental design with 21-day periods, and each square was blocked according to MY, BW and parity. The first 14 days were used for the cows' adaptation to the diets and the last 7 for the evaluation of DMI, MY, milk composition, total apparent digestibility of nutrients, diet composition and ruminal metabolism. The experiments were conducted sequentially, with experiment 2 following experiment 1 .

In experiments 1 and 2, the diets were formulated to be isoenergetic (1.57 NE/lkg DM and $1.55 \mathrm{NE}_{1} / \mathrm{kg} \mathrm{DM}$, respectively). Three CP levels (130, 160, and $180 \mathrm{~g}$ of CP/kg of $\mathrm{DM}$ ) were done in trial 1 , while in trial 2, the diets also were formulated to be isonitrogenous $(163 \mathrm{~g} \mathrm{CP} / \mathrm{kg}$ DM), but with three RDP contents $(80,100$, and $120 \mathrm{~g}$ of $\mathrm{RDP} / \mathrm{kg}$ of $\mathrm{DM}$ ). Both experiments used sugarcane silage as roughage, soybean meal, urea, rehydrated corn silage, corn gluten meal and mineral and vitamin supplement(Table 1). The amount of feed offered was calculated to allow daily orts of 5 to $10 \%$.
Sugarcane (Saccharum officinarum L.) variety IAC86-2480 (IAC/APTA, São Paulo, Brazil) was harvested by a forage harvester (Colhiflex; Menta Mit, Cajuru, SP, Brazil) adjusted for an average particle size of $10.8 \mathrm{~mm}$ (Lammers et al., 1996). The silage microbial inoculant (Lactobacillus buchneri, LalSil ${ }^{\circ}$ Cana - Lallemand, Brazil) was used at a concentration of $2 \mathrm{~g} /$ ton, by spraying a diluted solution $(100 \mathrm{~g} / 50 \mathrm{~L}$ of water) to achieve a standard rate of $4 \times 10^{5} \mathrm{CFU} / \mathrm{g}$ of fresh forage that was kept ensiled for $60 \mathrm{~d}$ before opening. The corn grains (variety Dow 2B710 HX'; Dow AgroScience, Mogi Mirim, SP, Brazil) were processed, rehydrated and inoculated according Arcari et al. (2016).

\section{Feed and feces analysis and total digestibility}

The samples of the feed ingredients, total diets, feces and orts were collected as proposed by Arcari et al. (2016) to determine the nutrients intake of dry matter, organic matter (OM), CP, NDF, ADF and ethereal extract (EE). They were stored at $-20^{\circ} \mathrm{C}$ until laboratory analysis.

Table 1 - Ingredients and chemical composition of diets with different levels of crude protein and protein degradability in the dairy cows rumen

\begin{tabular}{|c|c|c|c|c|c|c|}
\hline \multirow{3}{*}{ Item } & \multicolumn{3}{|c|}{ CP (g/kg DM) } & \multicolumn{3}{|c|}{ RDP (g/kg DM) } \\
\hline & 130 & 160 & 180 & 80 & 100 & 120 \\
\hline & \multicolumn{6}{|c|}{ g/kg DM } \\
\hline $\mathrm{SCS}^{\mathrm{a}}$ & 399.0 & 400.8 & 400.6 & 400.5 & 402.3 & 399.8 \\
\hline $\mathrm{RCS}^{\mathrm{b}}$ & 444.2 & 388.7 & 320.5 & 358.5 & 387.2 & 429.4 \\
\hline Soybean meal & 89.9 & 120.8 & 180.5 & 120.2 & 120.8 & 120.0 \\
\hline Corn gluten meal & 21.2 & 40.4 & 50.5 & 85.0 & 40.4 & - \\
\hline Urea & 6.7 & 8.8 & 8.0 & - & 8.8 & 17.9 \\
\hline Mineral mix ${ }^{c}$ & 23.4 & 24.9 & 24.3 & 21 & 24.9 & 22.3 \\
\hline Ammonium sulfate & 1.0 & 1.0 & 1.0 & 1.6 & 1.0 & 1.7 \\
\hline Sodium bicarbonate & 8.8 & 8.8 & 8.8 & 8.0 & 8.8 & 8.5 \\
\hline Magnesium oxide & 1.6 & 1.6 & 1.6 & 1.4 & 1.6 & 1.5 \\
\hline Dicalcium phosphate & 2.1 & 2.1 & 2.1 & 2.4 & 2.1 & 2.6 \\
\hline \multirow[t]{2}{*}{ Sodium Chloride } & 2.1 & 2.1 & 2.1 & 1.4 & 2.1 & 1.5 \\
\hline & \multicolumn{6}{|c|}{ Chemical composition g/kg DM } \\
\hline Dry matter & 434.4 & 439.6 & 435.6 & 470.8 & 470.4 & 470.3 \\
\hline $\mathrm{NE}_{\mathrm{L}}(\mathrm{Mcal} / \mathrm{kg})^{\mathrm{d}}$ & 1.56 & 1.58 & 1.57 & 1.58 & 1.55 & 1.53 \\
\hline Mineral matter & 66.2 & 62.3 & 67.6 & 62.1 & 60.5 & 63.2 \\
\hline Crude protein & 132.0 & 161.0 & 187.0 & 163.1 & 162.8 & 163.2 \\
\hline Starch & 306.4 & 268.2 & 221.1 & 247.3 & 267.1 & 272.3 \\
\hline Ethereal extract & 29.0 & 27.0 & 25.0 & 27.0 & 27.0 & 28.0 \\
\hline $\mathrm{NDF}^{\mathrm{e}}$ & 320.0 & 327.0 & 329.0 & 328.0 & 327.0 & 325.0 \\
\hline $\mathrm{ADF}^{f}$ & 199.0 & 204.0 & 207.0 & 206.0 & 204.0 & 203.0 \\
\hline Lignin & 30.0 & 29.0 & 28.0 & 31.0 & 30.0 & 32.0 \\
\hline $\mathrm{RDPg}$ & 82.0 & 100 & 116 & 80.0 & 100.0 & 120.0 \\
\hline RUPg $^{g}$ & 50.0 & 61.0 & 71.0 & 83.1 & 62.8 & 43.2 \\
\hline RDP: RUP ratio & 1.64 & 1.64 & 1.64 & 0.97 & 1.59 & 2.77 \\
\hline
\end{tabular}

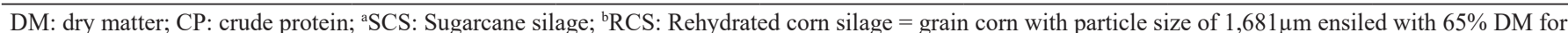
100 days prior delivery; ' per Kg: calcium - 190 g, phosphor -73 g, sulfur - 30 g, magnesium - 44 g, copper -340 mg, zinc -1350 mg, manganese - 940 mg, cobalt - $3 \mathrm{mg}$, iodine - $16 \mathrm{mg}$, selenium - $10 \mathrm{mg}$, iron - $1064 \mathrm{mg}$, vitamin A - $100.000 \mathrm{IU}$, vitamin D - 40.000 IU, vitamin E - $600 \mathrm{IU}$; NE $\mathrm{L}_{\mathrm{L}}$ net energy from National Research Council (2001); ${ }^{\mathrm{e}} \mathrm{NDF}=$ neutral detergent fiber; ${ }^{\mathrm{f}} \mathrm{ADF}=$ acid detergent fiber; ${ }^{\mathrm{R} D P}=$ rumen-degradable protein; RUP $=$ rumen-undegradable protein from National Research Council (2001). 
After thawing at room temperature, samples were pre-dried in a forced air oven $\left(60^{\circ} \mathrm{C}\right.$ for $\left.72 \mathrm{~h}\right)$ and milled in $1 \mathrm{~mm}$ porosity sieves (Marconi, MA 048 model). The analysis of dry matter, lignin, ethereal extract (EE) and ash were done according Association of Official Analytical Chemists (1990), described in more detail in Arcari et al. (2016). Concentrations of NDF and ADF were determined according to Van Soest et al. (1991) and total N content was determined based on DM basis for silage and concentrate and based on OM for feces and urine (Elementar Rapid N, method 990.03, Association of Official Analytical Chemists, 2000). The NDF, starch content and rehydrated corn silage analysis, including $\mathrm{pH}$ and particle size were determined using the same methodology described by Arcari et al. (2016). Geometric mean particle size (GMPS) evaluation was performed according Baker \& Hermann (2002) (Table 2).

The estimate of total fecal excretion and the total apparent digestibility of individual feeds, orts and feces were done as described by Arcari et al. (2016), using the indigestible acid detergent fiber (iADF) as an internal marker.

\section{Milk sampling and analyses}

The milk production was daily measured in the last 7 days of each experimental period by an electronic system (DeLaval, Campinas, Brazil). The fat milk production corrected to $3.5 \%$ (FCM) was calculated according to Sklan et al. (1994). Milk samples were collected from d 16 to 19 of each period, refrigerated and preserved with 2-bromo-2-nitropropane-1,3-diol ( $0.05 \% \mathrm{w} / \mathrm{v})$ and analyzed by infrared absorption (Bentley Instruments, 1995) for determination of fat, protein, lactose, total solids and casein. Analyses of urea nitrogen in milk were performed using an automated system based on the enzymatic spectrophotometric method (ChemSpeck 150 ${ }^{\circ}$, Bentley Instruments, Chaska, Minnesota, USA).

Table 2 - Chemical composition of dry corn, rehydrated corn silage, sugarcane silage and soybean meal of diets for dairy cows

\begin{tabular}{|c|c|c|c|c|}
\hline \multirow{2}{*}{ Nutrient } & GDC & RCS & SCS & SM \\
\hline & \multicolumn{4}{|c|}{ Chemical composition } \\
\hline $\mathrm{DM} \mathrm{g} / \mathrm{kg}$ & 870.0 & 670.0 & 310.7 & 875.3 \\
\hline $\mathrm{CP} \mathrm{g} / \mathrm{kg} \mathrm{MS}$ & 81.0 & 82.0 & 40.0 & 500.0 \\
\hline $\mathrm{SP}, \% \mathrm{CP}$ & 6.0 & 33.1 & - & - \\
\hline Starch g/kg DM & 693.0 & 695.0 & 10.0 & 40.0 \\
\hline NDF & 16.9 & 16.8 & 593.1 & 17.7 \\
\hline ADF & 3.3 & 3.2 & 460.3 & 10.5 \\
\hline $\mathrm{pH}$ & 6.1 & 3.9 & 4.0 & - \\
\hline GMPS $(\mu \mathrm{m})$ & - & 1.0 & - & - \\
\hline
\end{tabular}

GDC: ground dry corn; RCS: rehydrated corn silage; SCS: sugarcane silage; SM: soybean meal; -: not analyzed; DM: dry matter; CP: crude protein; SP: soluble protein; NDF: neutral detergent fiber; ADF: acid detergent fiber; GMPS: geometric mean particle size.

\section{Rumen fluid and urine analyses}

In the last days of collection of each experimental period, collections of ruminal liquid were carried out through esophageal probe and urine, collected after vulvar stimulation, as described by Arcari et al. (2016). The ruminal samples were processed for determination of ammoniacal nitrogen $\left(\mathrm{N}-\mathrm{NH}_{3}\right), \mathrm{N}$ balance (ingested - NI, feces - NF, urine - NU; total - NT) and short-chain fatty acids (SCFA). Urine analyses were performed to $\mathrm{pH}$, creatinine concentrations, estimative of total daily urine volume and the urinary creatinine excretion. Both analyses were done as described by Martins et al. (2016).

\section{Statistical analysis}

The data were analyzed using the MIXED procedure of SAS version 9.3 (SAS Institute Inc., 1995), after verification of the residual normality and variance homogeneity. The main effects of the treatments were evaluated according to the following model: $\mathrm{Y}_{\mathrm{ijk} /}=\mu+\mathrm{T}_{\mathrm{i}}+\mathrm{Q}_{\mathrm{j}}+\mathrm{A}(\mathrm{Q})_{\mathrm{k}}+\mathrm{P}_{1}+{ }_{\text {eijkl }}$ where $\mathrm{Y}_{\mathrm{ijk} \mathrm{k}}=$ is the observed value; $\mu$ = overall mean; $T_{i}=$ fixed treatment effect $i ; Q_{j}=$ random effect of Latin square $\mathrm{j}, \mathrm{j}=1$ to $3 ; \mathrm{A}(\mathrm{Q})_{\mathrm{k}}=$ random effect of animal $\mathrm{k}$ within each Latin square, $\mathrm{k}=1$ to $15 ; \mathrm{P}_{1}=$ random effect of period $1,1=1$ to $3 ; \mathrm{e}_{\mathrm{ijkl}}=$ random error associated with each observation. The degrees of freedom were calculated according to the Satterthwaite method (DDFM = SATTERTH) and the treatment effect was decomposed into 2 orthogonal polynomial contrasts (linear and quadratic). The orthogonal polynomials coefficients were obtained using the IML procedure of SAS because the treatments were not equally spaced. The significance of main effects was declared at $P<0.05$ and tendency to significance at $P<0.10$.

\section{Results}

\section{Nutrient intake and total tract apparent digestibility}

In experiment 1 , the intakes of $\mathrm{OM}, \mathrm{NDF}$ and $\mathrm{ADF}$ increased linearly $(P<0.05)$ according to the $\mathrm{CP}$ increase, but there was lower starch intake $(P<0.01)$. There was a linear increase in DM digestibility $(P=0.01)$ and $\mathrm{CP}$ digestibility $(P<0.01)$ coefficients according to $\mathrm{CP}$ increase content (Table 3). There was a tendency to increase the $\mathrm{DMI}$ when there was an increase of dietary $\mathrm{CP}(\mathrm{P}=0.06)$, as what was observed with $\mathrm{EE}$ too.

In experiment 2, DMI increased in a quadratic behavior according to the RDP content, and the optimum intake was around $100 \mathrm{~g} \mathrm{RDP} / \mathrm{kg} \mathrm{DM}(P=0.04)$. There was a linear increase of the starch intake $(P<0.01)$, but reduction of the $\mathrm{NDF}$ and ADF at the highest dose of RDP used $(P<0.05)$. 
Table 3 - Nutrient intake of dairy cows according to dietary protein content and protein degradability

\begin{tabular}{|c|c|c|c|c|c|c|c|c|c|c|c|c|}
\hline \multirow{2}{*}{ Nutrient } & \multicolumn{3}{|c|}{ g CP/kg DM } & \multirow{2}{*}{ SEM } & \multicolumn{2}{|c|}{$P$} & \multicolumn{3}{|c|}{ g RDP/kg DM } & \multirow{2}{*}{ SEM } & \multicolumn{2}{|c|}{$P$} \\
\hline & 130 & 160 & 180 & & $\mathbf{L}$ & $\mathbf{Q}$ & 80 & 100 & 120 & & $\mathbf{L}$ & $\mathbf{Q}$ \\
\hline & \multicolumn{12}{|c|}{ Intake (kg/d) } \\
\hline DM & 18.9 & 20.4 & 21.2 & 0.50 & 0.05 & 0.06 & 19.9 & 20.4 & 19.1 & 0.44 & 0.13 & 0.04 \\
\hline OM & 17.9 & 19.0 & 19.9 & 0.47 & 0.02 & 0.07 & 18.8 & 19.4 & 18.2 & 0.41 & 0.24 & 0.05 \\
\hline Starch & 6.02 & 5.63 & 4.70 & 0.15 & $<0.01$ & 0.06 & 5.51 & 5.76 & 6.07 & 0.12 & $<0.01$ & 0.83 \\
\hline NDF & 5.68 & 6.20 & 6.30 & 0.15 & $<0.01$ & 0.41 & 5.97 & 6.02 & 5.58 & 0.13 & 0.03 & 0.10 \\
\hline $\mathrm{EE}$ & 0.45 & 0.55 & 0.55 & 0.01 & 0.07 & 0.32 & 0.60 & 0.62 & 0.56 & 0.01 & 0.24 & $<0.01$ \\
\hline \multirow[t]{2}{*}{ ADF } & 4.20 & 4.54 & 4.63 & 0.11 & $<0.01$ & 0.05 & 4.70 & 4.72 & 4.37 & 0.10 & 0.01 & 0.11 \\
\hline & \multicolumn{12}{|c|}{ Coefficients of total tract apparent digestibility } \\
\hline DM & 0.64 & 0.68 & 0.70 & 0.003 & 0.01 & 0.18 & 0.67 & 0.69 & 0.67 & 0.006 & 0.59 & 0.08 \\
\hline $\mathrm{OM}$ & 0.71 & 0.71 & 0.71 & 0.003 & 0.06 & 0.28 & 0.70 & 0.71 & 0.70 & 0.005 & 0.79 & 0.12 \\
\hline $\mathrm{CP}$ & 0.80 & 0.80 & 0.83 & 0.006 & $<0.01$ & 0.80 & 0.84 & 0.83 & 0.82 & 0.006 & 0.39 & 0.93 \\
\hline Starch & 0.98 & 0.97 & 0.98 & 0.001 & 0.21 & 0.62 & 0.97 & 0.97 & 0.97 & 0.001 & 0.65 & 0.24 \\
\hline NDF & 0.40 & 0.39 & 0.42 & 0.009 & 0.34 & 0.16 & 0.39 & 0.42 & 0.34 & 0.013 & 0.75 & 0.01 \\
\hline $\mathrm{EE}$ & 0.67 & 0.67 & 0.67 & 0.016 & 0.81 & 0.43 & 0.72 & 0.77 & 0.65 & 0.013 & 0.67 & $<0.01$ \\
\hline ADF & 0.43 & 0.42 & 0.45 & 0.007 & 0.19 & 0.16 & 0.45 & 0.48 & 0.41 & 0.012 & 0.87 & $<0.01$ \\
\hline
\end{tabular}

DM: dry matter; OM: organic matter; CP: crude protein; RDP: rumen-degradable protein; NDF: neutral detergent fiber; EE: ethereal extract; ADF: acid detergent fiber; L: linear; Q: quadratic; SEM: Standard error mean; $P: P$ value.

Furthermore, the coefficients of NDF, ADFD and EE were higher when the RDP was around $100 \mathrm{~g} / \mathrm{kg} \mathrm{DM}$ (Table 3).

\section{Milk production and composition}

In experiment $1, \mathrm{MY}$ increased linearly $(P<0.01)$ according to the increase of $\mathrm{CP}$ content. Cows fed $180 \mathrm{~g} \mathrm{CP} / \mathrm{kg}$ DM produced $2.67 \mathrm{~kg} / \mathrm{d}$ more milk than those fed $130 \mathrm{~g} \mathrm{CP} / \mathrm{kg} \mathrm{DM}$. The FCM production also increased linearly $(P<0.01)$ according to the increase of $\mathrm{CP}$ content, and cows fed $180 \mathrm{~g} \mathrm{CP} / \mathrm{kg}$ DM produced $3.56 \mathrm{~L} / \mathrm{d}$ more FCM than those fed with $130 \mathrm{~g} \mathrm{CP} / \mathrm{kg} \mathrm{DM}$. The milk levels of fat $(P=0.04)$, protein $(P=0.02)$, casein $(P<0.01)$ and lactose $(P<0.01)$ increased linearly according to the $\mathrm{CP}$, and cows fed $180 \mathrm{~g} \mathrm{CP} / \mathrm{kg}$ DM increased $8.3 \%$ more casein than cows fed $130 \mathrm{~g} \mathrm{CP} / \mathrm{kg}$ of DM. Similarly, milk total solids increased linearly according to the $\mathrm{CP}$ content increase of 130 to $160 \mathrm{~g} \mathrm{CP} / \mathrm{kg}$ DM (11.91 vs $12.23 \mathrm{~g} / 100 \mathrm{~g}$ ) $(P=0.01)$. With the increase of $\mathrm{CP}$, the production of milk urea nitrogen (MUN) $(P<0.01)$, fat $(P<0.01)$, protein $(P$ $<0.01)$, casein $(P<0.01)$ and total solids $(P<0.01)$ increased linearly.

In experiment 2 , the MY had a quadratic effect according to dietary RDP content. Cows fed an intermediate RDP content (100 g RDP $/ \mathrm{kg} \mathrm{DM}$ ) produced $2.54 \mathrm{~kg} / \mathrm{d}$ more milk than when fed a high RDP (120g RDP/kg DM). Similarly, the FCM $(P<0.01)$, protein content $(P<0.01)$ and casein $(P<0.01)$ had the highest production when cows were fed $100 \mathrm{~g} \mathrm{RDP} / \mathrm{kg}$ DM. Lactose content decreased linearly $(P=0.03)$ from 4.42 to $4.37 \mathrm{~g} / 100 \mathrm{~g}$ with the increased RDP from 80 to $120 \mathrm{~g} \mathrm{RDP} / \mathrm{kg} \mathrm{DM}$ while fat content was not altered by the RDP content $(P>0.05)$. The daily production of fat $(P=0.03)$, protein $(P<0.01)$, casein $(P<0.01)$, lactose $(P<0.01)$ and total solids $(P<0.01)$ had a quadratic effect according to the RDP content, with higher yields occurring around $100 \mathrm{~g} \mathrm{RDP} / \mathrm{kg} \mathrm{DM}$ (Table 4).

\section{Ruminal $\mathrm{pH}, \mathrm{SCFA}$ and $\mathrm{N}-\mathrm{NH}_{3}$ concentration}

In experiment 1 , the concentration of $\mathrm{N}-\mathrm{NH}_{3}$ increased linearly with the increase of $\mathrm{CP}$ content and cows that were fed $180 \mathrm{~g} \mathrm{CP} / \mathrm{kg}$ DM had a N-NH $\mathrm{N}_{3}$ ruminal concentration 2.17 times higher than when fed with $130 \mathrm{~g} \mathrm{CP} / \mathrm{kg} \mathrm{DM}$. The concentrations of acetic acid $(P=0.08)$ and propionic acid $(P=0.09)$ tended to have a linear effect according to the $\mathrm{CP}$ content. The remaining SCFA and ruminal $\mathrm{pH}$ were not altered by the $\mathrm{CP}$ content.

In experiment 2 , the ruminal $\mathrm{pH}$ was reduced in a quadratic manner according to the increase in RDP content $(P<0.01)$. The concentration of propionic acid had a quadratic effect and increased by approximately $4 \mathrm{mmol} / \mathrm{L}$ from $80 \mathrm{~g}$ RDP for $100 \mathrm{~g} P \mathrm{PR} / \mathrm{kg} \mathrm{DM}(P=0.03)$. The concentration of acetic acid tends to have a linear effect with the increase of RDP content $(P=0.05)$ and the same linear effect occurs with the concentrations of iso-butyric and valeric acids. The remaining SCFA was not altered by the variation of RDP content. Furthermore, the increase of RDP content led to a linear increase of $\mathrm{N}-\mathrm{NH}_{3}$ concentrations of ruminal fluid $(P<0.01)$ (Table 5).

\section{Nitrogen balance and nitrogen use efficiency for milk production}

The nitrogen intake (g/day) increased linearly $(P<0.01)$ according to the increase in $\mathrm{CP}$ content in the diet, and 
Table 4 - Effect of dietary protein content and protein degradability on milk production and composition of dairy cows

\begin{tabular}{|c|c|c|c|c|c|c|c|c|c|c|c|c|}
\hline \multirow{2}{*}{ Variable } & \multicolumn{3}{|c|}{ g CP/kg DM } & \multirow{2}{*}{ SEM } & \multicolumn{2}{|c|}{$P$} & \multicolumn{3}{|c|}{ g RDP/kg DM } & \multirow{2}{*}{ SEM } & \multicolumn{2}{|c|}{$P$} \\
\hline & 130 & 160 & 180 & & $\mathbf{L}$ & $\mathbf{Q}$ & 80 & 100 & 120 & & $\mathbf{L}$ & $\mathbf{Q}$ \\
\hline & \multicolumn{12}{|c|}{ kg/cow/day } \\
\hline MY & 27.6 & 29.8 & 30.3 & 0.66 & $<0.01$ & 0.13 & 27.5 & 28.0 & 25.4 & 0.54 & $<0.01$ & $<0.01$ \\
\hline \multirow[t]{2}{*}{ FCM } & 27.9 & 30.6 & 31.4 & 0.77 & $<0.01$ & 0.20 & 28.3 & 29.4 & 26.2 & 0.87 & 0.02 & $<0.01$ \\
\hline & \multicolumn{12}{|c|}{ g/kg } \\
\hline Fat & 35.3 & 36.7 & 37.1 & 0.6 & 0.04 & 0.75 & 36.6 & 37.4 & 36.4 & 1.1 & 0.91 & 0.52 \\
\hline Protein & 28.2 & 28.7 & 29.0 & 0.3 & 0.02 & 0.83 & 29.3 & 29.8 & 28.2 & 0.3 & $<0.01$ & $<0.01$ \\
\hline Lactose & 44.6 & 44.8 & 45.2 & 0.3 & $<0.01$ & 0.64 & 44.2 & 44.0 & 43.7 & 0.3 & 0.03 & 0.98 \\
\hline TS & 119 & 122 & 122 & 1.1 & 0.01 & 0.10 & 121 & 122 & 119 & 1.5 & 0.36 & 0.36 \\
\hline \multirow[t]{2}{*}{ Casein } & 20.8 & 21.7 & 23.2 & 0.2 & $<0.01$ & 0.04 & 22.2 & 22.5 & 21.3 & 0.3 & $<0.01$ & $<0.01$ \\
\hline & \multicolumn{12}{|c|}{$m g / d L$} \\
\hline \multirow[t]{2}{*}{ MUN } & 12.7 & 17.4 & 18.9 & 0.55 & $<0.01$ & 0.32 & 15.0 & 16.3 & 19.1 & 0.38 & $<0.01$ & 0.57 \\
\hline & \multicolumn{12}{|c|}{ kg/cow/day } \\
\hline Fat & 0.98 & 1.08 & 1.12 & 0.03 & $<0.01$ & 0.28 & 1.01 & 1.06 & 0.93 & 0.04 & 0.12 & 0.03 \\
\hline Protein & 0.78 & 0.85 & 0.88 & 0.02 & $<0.01$ & 0.10 & 0.80 & 0.83 & 0.71 & 0.01 & $<0.01$ & $<0.01$ \\
\hline Lactose & 1.23 & 1.35 & 1.37 & 0.03 & $<0.01$ & 0.03 & 1.21 & 1.23 & 1.11 & 0.02 & $<0.01$ & $<0.01$ \\
\hline Casein & 0.57 & 0.64 & 0.70 & 0.01 & $<0.01$ & 0.47 & 0.61 & 0.63 & 0.54 & 0.01 & $<0.01$ & $<0.01$ \\
\hline TS & 3.30 & 3.66 & 3.71 & 0.09 & $<0.01$ & 0.06 & 3.34 & 3.44 & 3.06 & 0.09 & $<0.01$ & $<0.01$ \\
\hline
\end{tabular}

MY: milk yield; FCM: fat corrected milk for 3.5\%; TS: total solids; MUN: milk urea nitrogen; CP: crude protein; DM: dry matter; RDP: rumen-degradable protein; L: linear; Q: quadratic; SEM: Standard error mean; $P: P$ value.

Table 5 - Adjusted means for the effect of protein content and protein degradability on short-chain fatty acids and ammoniacal nitrogen of dairy cows

\begin{tabular}{|c|c|c|c|c|c|c|c|c|c|c|c|c|}
\hline \multirow{2}{*}{ Variables } & \multicolumn{3}{|c|}{ g CP/kg DM } & \multirow{2}{*}{ SEM } & \multicolumn{2}{|c|}{$P$} & \multicolumn{3}{|c|}{ g RDP/kg DM } & \multirow{2}{*}{ SEM } & \multicolumn{2}{|c|}{$P$} \\
\hline & 130 & 160 & 180 & & $\mathbf{L}$ & $\mathbf{Q}$ & 80 & 100 & 120 & & $\mathbf{L}$ & $\mathbf{Q}$ \\
\hline \multirow[t]{2}{*}{$\mathrm{pH}$} & 6.54 & 6.59 & 6.61 & 0.22 & 0.33 & 0.88 & 6.46 & 6.27 & 6.53 & 0.04 & 0.39 & $<0.01$ \\
\hline & \multicolumn{12}{|c|}{$\mathrm{mmol} / \mathrm{L}$} \\
\hline Acetic acid & 45.4 & 45.9 & 49.4 & 1.15 & 0.08 & 0.45 & 51.5 & 53.0 & 48.2 & 1.31 & 0.05 & 0.52 \\
\hline Propionic acid & 15.4 & 14.7 & 13.7 & 0.44 & 0.09 & 0.90 & 17.0 & 20.5 & 16.4 & 0.97 & 0.74 & 0.03 \\
\hline Butyric acid & 11.7 & 11.2 & 11.6 & 0.35 & 0.84 & 0.52 & 13.0 & 12.7 & 11.4 & 0.54 & 0.15 & 0.56 \\
\hline Isobutyric acid & 0.91 & 0.87 & 0.84 & 0.03 & 0.51 & 0.90 & 1.09 & 0.95 & 0.93 & 0.03 & 0.07 & 0.38 \\
\hline Valeric acid & 1.34 & 1.27 & 1.24 & 0.03 & 0.23 & 0.77 & 1.58 & 1.55 & 1.58 & 0.09 & 0.06 & 0.32 \\
\hline \multirow[t]{2}{*}{ Iso-valeric acid } & 1.82 & 1.79 & 1.68 & 0.06 & 0.35 & 0.79 & 2.13 & 2.08 & 2.17 & 0.07 & 0.85 & 0.67 \\
\hline & \multicolumn{12}{|c|}{$m g / d L$} \\
\hline $\mathrm{NH}_{3}-\mathrm{N}$ & 12.1 & 18.2 & 26.3 & 1.2 & $<0.01$ & 0.52 & 11.5 & 18.0 & 27.5 & 1.86 & $<0.01$ & 0.56 \\
\hline
\end{tabular}

CP: crude protein; DM: dry matter; $\mathrm{NH}_{3}-\mathrm{N}$ : ammoniacal nitrogen; $\mathrm{CP}$ : crude protein; RDP: rumen-degradable protein; L: linear; Q: quadratic; SEM: Standard error mean; $P: P$ value.

cows fed $180 \mathrm{~g} \mathrm{CP} / \mathrm{kg}$ DM consumed $200 \mathrm{~g}$ more $\mathrm{N}$ of than animals fed $130 \mathrm{~g} \mathrm{CP} / \mathrm{kg}$ DM. Similarly, excretions of nitrogen in feces $(P=0.03)$, urine $(P<0.01)$ and milk $(P<0.01)$ increased linearly according to the $\mathrm{CP}$ content. However, excretion of $\mathrm{N}$ in feces and milk (percentage of ingested $\mathrm{N}$ ) were linearly reduced with increasing $\mathrm{CP}$ content, whereas excretion of $\mathrm{N}$ in urine (percentage of ingested $\mathrm{N})$ showed a quadratic effect $(P=0.02)$. The $\mathrm{N}$ balance (retention; $\mathrm{g} / \mathrm{d}$ ) increased linearly with the increase of CP content $(P<0.01)$.

In experiment 2 , the nitrogen intake had a quadratic effect according to the increase of RDP content, and the lowest intake was observed with $120 \mathrm{~g} \mathrm{RDP} / \mathrm{kg}$ DM. The increase of RDP content linearly increased the excretion of NU $(P=0.04)$. The excretion of NM showed a quadratic effect, with the lowest excretion of NM observed with the inclusion of $120 \mathrm{~g} \mathrm{RDP} / \mathrm{kg}$ $\mathrm{DM}(P<0.01)$. The balance of $\mathrm{N}$ had a quadratic effect observed $(P=0.02)$ according to the RDP content and the lowest balance was observed with the inclusion of $120 \mathrm{~g} \mathrm{RDP} / \mathrm{kg}$ DM. The excretion of nitrogen in feces tended to have a linear decrease with the increase of RDP ( $\mathrm{P}=0.05)$. The protein excretion in milk (percentage of ingested $\mathrm{N}$ ) increased in a quadratic manner according to the RDP content $(P<0.01)$, with the lowest excretion observed with $120 \mathrm{~g}$ RDP $/ \mathrm{kg}$ DM. The excretion of nitrogen in feces decreased linearly with increasing RDP content $(P=0.03)$, while the excretion of nitrogen in urine increased linearly $(P<0.01)$, both like a percentage of ingested $\mathrm{N}$ (Table 6). 


\section{Discussion}

In the present study, there was only a trend to a DMI increase as $\mathrm{CP}$ content of the diet increased. Similarly, no effects on DMI were observed in dairy cows of $20 \mathrm{~kg}$ milk/ day and 110 DIM when the CP level increased from 11.3 to $14.4 \%$ of DM (Pereira et al., 2005). On the other hand, some studies have reported a linear increase in DMI by increasing CP levels in the diet of dairy cows (Colmenero \& Broderick, 2006a; Ipharraguerre \& Clark, 2005). These differences can be explained by the variation of RDP:RUP ratio and dietary characteristics such as ruminal fiber digestibility and NFC source (Broderick et al., 2009). Similarly to the present study, Kalscheur et al. (2006) did not observe effects on DMI in diets with high RDP content. Otherwise, increasing the RDP:RUP ratio from 60:40 to 65:45 was observed to increase milk yield and dietary $\mathrm{N}$ use efficiency (Savari et al., 2018). These authors have associated these effects possibly with the lower microbial protein synthesis and/or lower intestinal digestibility of the source of RUP used and the lower ratio RDP:RUP (soybean meal treated with xylose). Indeed, the reduction of the RDP:RUP ratio from 60:40 to 50:50 limited the microbial protein synthesis, but did not alter the productive performance of cows (Savari et al., 2018). Thus, the effects of the RDP:RUP ratio on MY depend on the relationship between how they are used and the sources used as RDP and RUP.

In the present study, the increase of DMI due to increased $\mathrm{RDP}$ may indicate that diets with $80 \mathrm{~g} \mathrm{RDP} / \mathrm{kg} \mathrm{DM}$ may have limited the microbial protein synthesis and ruminal fermentability of the fiber, while the inclusion of $100 \mathrm{~g}$ $\mathrm{RDP} / \mathrm{kg} \mathrm{DM}$ may have optimized ruminal metabolism, explained by the increase on NDF digestibility. However, increasing the RDP inclusion from 100 to $120 \mathrm{~g} \mathrm{RDP} / \mathrm{kg}$ DM did not increase ruminal fermentation and microbial activity and decreased DMI. This decrease can be explained by the lowest value of NDF digestibility (0.34), which increased the digestive tract time and inhibited the DMI. Moreover, the metabolic effects and low palatability of urea may have contributed to lower CMS, although the diet was provided as a TMR. Huber \& Cook (1972) suggested that the reduction of DMI in response to urea inclusion is due to low palatability and not because of ruminal or postruminal effects. However, cows cannot dislike the flavor of urea per se, but they could identify different levels of urea in rations, and develop an aversion when it is fed at higher levels (Kertz, 2010).

The linear increase of MY, FCM and milk solids production according to the increase of $\mathrm{CP}$ content in the present study may be associated with greater DM and CP intake. Similarly, the increases of MY, FCM and total solids according to the RDP inclusion can also be associated with DMI since this variable increased with increasing of RDP content. Broderick (2003) also observed increased MY, FCM and milk protein according to the increase in $\mathrm{CP}$ content of the diet (15.1, 16.7 and 18.4\%). Pereira et al. (2005) observed a linear increase in the FCM, fat and protein production per day in cows in the middle third of lactation when fed diets with increasing CP levels (11.3, 12.3, 13.3 and 14.4\%). The results of the present study, as well as those of Broderick (2003), confirm the hypothesis that the increase of CP content increases availability of metabolizable protein and amino acids for use by the mammary gland, beyond the increase of glucose synthesis from non-used AAs.

In the present study, the linear increase of apparent total digestibility of $\mathrm{CP}$ according to the increase in $\mathrm{CP}$ content may be related to the effect of fecal metabolic nitrogen dilution (Broderick, 2003; Colmenero \& Broderick, 2006b; Pereira et al., 2005). In some studies, increased digestibility of DM, OM, CP and NDF was observed with increasing CP content of the diet (Broderick, 2003; Colmenero \& Broderick, 2006a; Pereira et al., 2005). There was greater apparent digestibility of DM and $\mathrm{CP}$ as $\mathrm{CP}$ concentration in the diet increased, indicating that the rumen environment benefited, resulting in greater intake and MY. The lack of effect on NDF is totally expected once the ruminal passage rate increases with intake (Dado \& Allen, 1995), diminishing the time that fiber stays in the rumen to be digested.

Urinary $\mathrm{N}$ excretion was greater for cows fed higher $\mathrm{CP}$ and RDP content, suggesting that these diets produced higher amounts of $\mathrm{N}-\mathrm{NH}_{3}$ in the rumen, which was observed in both experiments. The absorption of $\mathrm{N}_{-} \mathrm{NH}_{3}$ by the ruminal epithelium resulted in increased production of blood urea via the urea cycle. Thus, when cows are fed higher levels of $\mathrm{CP}$ or $\mathrm{RDP}$, there is a greater excretion of urinary $\mathrm{N}$ to eliminate blood urea $\mathrm{N}$. In a review about the efficiency of nitrogen use in diets of dairy cows, Castillo et al. (2000) reported that when $\mathrm{N}$ ingestion was greater than $400 \mathrm{~g}$ $\mathrm{N} / \mathrm{d}$, the $\mathrm{N}$ urinary excretion increased exponentially, but the rate of $\mathrm{N}$ excretion in feces decreased linearly, as we observed in this study with the RDP increase. This fact emphasizes the importance of the dietary $\mathrm{N}$ balance, as increasing $\mathrm{CP}$ or RDP increases $\mathrm{N}$ elimination by milk and urine. These authors suggested that the use of $150 \mathrm{~g}$ of $\mathrm{CP} / \mathrm{kg} \mathrm{DM}$ would be an optimal value to reduce the excretion of urinary N, without altering MY. However, these results should be interpreted with caution, since the RDP:RUP ratio, metabolizable protein content and amino acid profile can also determine the optimum CP 
content to optimize productive performance and reduce $\mathrm{N}$ excretion (Broderick et al., 2009). The results of experiment 1 indicated that inclusion of RUP up to $100 \mathrm{~g} / \mathrm{kg}$ optimized milk protein synthesis, and inclusions above this content resulted only in increased urine $\mathrm{N}$ excretion and MUN. Increasing urinary $\mathrm{N}$ excretion and $\mathrm{MUN}$, and reducing fecal $\mathrm{N}$ excretion, is due to the higher amount of NNP in the rumen-absorbed diet and the lower amount of RUP, which is intended for intestinal absorption.

The reduction of CP content from 15.4 to $12.4 \%$ of DM reduced urinary $\mathrm{N}$ excretion and did not alter milk protein content (Agle et al., 2010). Different from our study, Savari et al. (2018) observed greater efficiency of N use by increasing the RDP:RUP ratio from 60:40 to 65:45, due to greater $\mathrm{N}$ secretion in milk. In the present study, there was an effect of CP and RDP levels on the feces $\mathrm{N}$ excretion (g/d). Reduction of fecal $\mathrm{N}$ was observed for diets with higher inclusion of RDP, since the available $\mathrm{N}$ in the rumen could be used by the ruminal microbiota or be absorbed as $\mathrm{N}-\mathrm{NH}_{3}$ and eliminated in urine and milk, resulting in a lower $\mathrm{N}$ flux to the gut and fecal excretion. Mendonça et al. (2004) did not observe an increase in the excretion of $\mathrm{N}$ in feces with urea inclusion ( 0.35 or $1 \% \mathrm{DM}$ ) in the diet. In another study, the increase in $\mathrm{CP}$ content of the diet also had no effect on fecal $\mathrm{N}$ excretion (Agle et al., 2010).

In the present study, there was a greater amount of nitrogen secreted by milk as a proportion to total $\mathrm{N}$ intake of cows fed diets with low $\mathrm{CP}$, which resulted in a higher efficiency of $\mathrm{N}$ ingestion for conversion to milk protein, but leading to reduction of the MY. Previous studies have also observed a higher efficiency of dietary $\mathrm{N}$ utilization after a reduction of total dietary N (Broderick \& Reynal, 2009; Colmenero \& Broderick, 2006a; Lee et al., 2012).

\section{References}

Agle M, Hristov AN, Zaman S, Schneider C, Ndegwa PM, Vaddella VK. Effect of dietary concentrate on rumen fermentation, digestibility, and nitrogen losses in dairy cows. J Dairy Sci. 2010;93(9):4211-22. http://dx.doi.org/10.3168/ jds.2009-2977. PMid:20723695.

AOAC: Association of Official Analytical Chemists. International official methods of analysis. 15th ed. Washington: AOAC; 1990.

AOAC: Association of Official Analytical Chemists. Official methods of analysis of the Association of the Analytical Chemists. 17th ed. Virginia: AOAC; 2000.
We observed that an increase of CP levels from 130 to $180 \mathrm{~g} \mathrm{CP} / \mathrm{kg}$ DM increased DMI and performance of dairy cows, but there was a reduction in the efficiency of dietary $\mathrm{N}$ utilization. Inclusion of $100 \mathrm{~g} \mathrm{RDP} / \mathrm{kg} \mathrm{DM}$ optimized $\mathrm{DMI}$ and performance, but urine $\mathrm{N}$ elimination increased linearly with RDP inclusion from 80 to $120 \mathrm{~g} \mathrm{RDP} / \mathrm{kg} \mathrm{DM}$. Therefore, it is advisable that the increase of CP through increased RDP should be up to values close to $100 \mathrm{~g} \mathrm{RDP} / \mathrm{kg}$ of DM, and values above this should be supplied using high quality rumen bypass protein to optimize performance production and $\mathrm{N}$ use efficiency of dairy cows.

\section{Conclusion}

The CP levels from 130 to $180 \mathrm{~g} \mathrm{CP} / \mathrm{kg} \mathrm{DM}$, through increased RDP levels to values close to $100 \mathrm{~g} \mathrm{RDP} / \mathrm{kg}$ of $\mathrm{DM}$, increased DMI and performance of dairy cows with an increase of ammoniacal nitrogen. However, this increase of protein availability can lead to a reduction in the efficiency of dietary $\mathrm{N}$ utilization.

\section{Conflict of Interest}

The author(s) declare(s) that there is no conflict of interest regarding the publication of this article.

\section{Ethics Statement}

This study was approved by the Ethics Committee on Animal Use of the School of Veterinary Medicine and Animal Science (CEUA/FMVZ/USP - protocol number 2671/2012).

\section{Acknowledgements}

We are grateful to FAPESP (São Paulo State Research Support Foundation) for the scholarship (2014/20877-4 and 2012/13992-9) and Suzanne Kane for English revision.

Arcari MA, Martins CMMR, Tomazi T, Gonçalves JL, Santos MV. Effect of substituting dry corn with rehydrated ensiled corn on dairy cow milk yield and nutrient digestibility. Anim Feed Sci Technol. 2016;221:167-73. http://dx.doi. org/10.1016/j.anifeedsci.2016.08.005.

Bahrami-Yekdangi H, Khorvash M, Ghorbani GR, Alikhani M, Jahanian R, Kamalian E. Effects of decreasing metabolizable protein and rumen-undegradable protein on milk production and composition and blood metabolites of Holstein dairy cows in early lactation. J Dairy Sci. 2014;97(6):3707-14. http://dx.doi.org/10.3168/jds.2013-6725. PMid:24679928. 
Baker S, Hermann TL. Evaluating particle size. Manhattan (KS): Department of Grain Science and Industry. Kansas State University: 2002. Publ. MF-2051.

Bentley Instruments. Bentley 2000: operator's manual. Chaska (MN): Bentley Instruments; 1995.

Broderick GA. Effects of varying dietary protein and energy levels on the production of lactating dairy cows. J Dairy Sci. 2003;86(4):1370-81. http://dx.doi.org/10.3168/jds. S0022-0302(03)73721-7. PMid:12741562.

Broderick GA, Reynal SM. Effect of source of rumendegraded protein on production and ruminal metabolism in lactating dairy cows. J Dairy Sci. 2009;92(6):2822-34. http://dx.doi.org/10.3168/jds.2008-1865. PMid:19448016.

Broderick GA, Stevenson MJ, Patton RA. Effect of dietary protein concentration and degradability on response to rumen-protected methionine in lactating dairy cows. J Dairy Sci. 2009;92(6):2719-28. http://dx.doi.org/10.3168/ jds.2008-1277.

Castillo AR, Kebreab E, Beever DE, France J. A review of efficiency of nitrogen utilization in dairy cows and its relationship with the environmental pollution. J Anim Feed Sci. 2000;9(1):1-32. http://dx.doi.org/10.22358/ jafs/68025/2000.

Colmenero JJO, Broderick GA. Effect of dietary crude protein concentration on ruminal nitrogen metabolism in lactating dairy cows. J Dairy Sci. 2006a;89(5):1694-703. http://dx.doi.org/10.3168/jds.S0022-0302(06)72237-8. PMid:16606740.

Colmenero JJO, Broderick GA. Effect of dietary crude protein concentration on milk production and nitrogen utilization in lactating dairy cows. J Dairy Sci. 2006b;89(5):1704-12. http://dx.doi.org/10.3168/jds.S0022-0302(06)72238-X. PMid:16606741.

Dado RG, Allen MS. Intake limitations, feeding behavior, and rumen function of cows challenged with rumen fill from dietary fiber or inert bulk. J Dairy Sci. 1995;78(1):11833. http://dx.doi.org/10.3168/jds.S0022-0302(95)76622-X. PMid:7738249.

Huber JT, Cook RM. Influence of site of administration of urea on voluntary intake of concentrate by lactating cows. J Dairy Sci. 1972;55(10):1470-3. http://dx.doi.org/10.3168/ jds.S0022-0302(72)85696-0. PMid:4672907.
Ipharraguerre IR, Clark JH. Varying protein and starch in the diet of dairy cows. II. Effects on performance and nitrogen utilization for milk production. J Dairy Sci. 2005;88(7):2556-70. http://dx.doi.org/10.3168/jds.S00220302(05)72932-5. PMid:15956317.

Kalscheur KF, Baldwin RL 6th, Glenn BP, Kohn RA. Milk production of dairy cows fed differing concentrations of rumen-degraded protein. J Dairy Sci. 2006;89(1):249-59. http://dx.doi.org/10.3168/jds.S0022-0302(06)72089-6. PMid:16357288.

Kebreab E, France J, Beever DE, Castillo AR. Nitrogen pollution by dairy cows and its mitigation. nutrient cycling in agroecosystems. Nutr Cycl Agroecosyst. 2001;60(1/3):27585. http://dx.doi.org/10.1023/A:1012668109662.

Kertz AF. Urea feeding to dairy cattle: a historical perspective and review. Prof Anim Sci. 2010;26(3):257-72. http://dx.doi. org/10.15232/S1080-7446(15)30593-3.

Lammers BP, Buckmaster DR, Heinrichs AJ. A simple method for the analysis of particle sizes of forage and total mixed rations. J Dairy Sci. 1996;79(5):922-8. http://dx.doi. org/10.3168/jds.S0022-0302(96)76442-1. PMid:8792291.

Lee C, Hristov AN, Cassidy TW, Heyler KS, Lapierre H, Varga GA, de Veth MJ, Patton RA, Parys C. Rumen-protected lysine, methionine, and histidine increase milk protein yield in dairy cows fed a metabolizable protein-deficient diet. J Dairy Sci. 2012;95(10):6042-56. http://dx.doi.org/10.3168/ jds.2012-5581. PMid:22863104.

Martins CMMR, Arcari MA, Welter K, Gonçalves JL, Santos MV. Effect of dietary cation-anion difference on ruminal metabolism, total apparent digestibility, blood and renal acid-base regulation in lactating dairy cows. Animal. 2016;10(1):64-74. http://dx.doi.org/10.1017/ S1751731115001548. PMid:26289745.

Mendonça SS, Campos JMS, Valadares SC Fo. Intake, apparent digestibility, milk production and composition and ruminal variables of dairy cows fed sugar cane based diets. Rev Bras Zootec. 2004;33:481-92. http://dx.doi. org/10.1590/S1516-35982004000200027.

Mutsvangwa T, Davies KL, McKinnon JJ, Christensen DA. Effects of dietary crude protein and rumen-degradable protein concentrations on urea recycling, nitrogen balance, omasal nutrient flow, and milk production in dairy cows. J Dairy Sci. 2016;99(8):6298-310. http://dx.doi.org/10.3168/ jds.2016-10917. PMid:27236760. 
NRC: National Research Council. Nutrient Requirements of Dairy Cattle. 7th rev. ed. Washington: NRC; 2001.

Pereira MLA, Valadares SC Fo, Valadares RFD. Intake, total apparent digestibility, milk production and composition in mid lactation cows fed with increasing levels of crude protein in the concentrate. Rev Bras Zootec. 2005;34(3):1029-39. http://dx.doi.org/10.1590/ S1516-35982005000300036.

Rius AGS, Kittelmann S, MacDonald KA, Waghorn GC, Janssen PH, Sikkema E. Nitrogen metabolism and rumen microbial enumeration in lactating cows with divergent residual feed intake fed high-digestibility pasture. J Dairy Sci. 2012;95(9):5024-34. http://dx.doi.org/10.3168/jds.20125392. PMid:22916906.

SAS Institute Inc. SAS/STATTM. SAS user's guide for windowns environment. 6.11 ed. Cary: SAS Institute; 1995.

Savari M, Khorvash M, Amanlou H, Ghorbani GR, Ghasemi E, Mirzaei M. Effects of rumen-degradable protein:rumen-undegradable protein ratio and corn processing on production performance, nitrogen efficiency, and feeding behavior of holstein dairy cows. J Dairy Sci. 2018;101(2):1111-22. http://dx.doi.org/10.3168/jds.201712776. PMid:29224859.
Sklan D, Kaim M, Moallem U, Folman Y. Effect of dietary calcium soaps on milk yield, body weight, reproductive hormones, and fertility in first parity and older cows. J Dairy Sci. 1994;77(6):1652-60. http://dx.doi.org/10.3168/ jds.S0022-0302(94)77107-1. PMid:8083425.

Van Soest PJ, Robertson JB, Lewis BA. Methods for dietary fiber, neutral detergent fiber, and nonstarch polysaccharides in relation to animal nutrition. J Dairy Sci. 1991;74(10):358397. http://dx.doi.org/10.3168/jds.S0022-0302(91)78551-2. PMid:1660498.

Vaz Pires A, Susin I, Santos FAP, Mendes CQ, Oliveira RC Jr, Fernandes JJR, Simas JMC. Effect of starch sources and processing on performance and nitrogen metabolism in lactating holstein cows. Rev Bras Zootec. 2008;37(8):145662. http://dx.doi.org/10.1590/S1516-35982008000800017.

Wang C, Liu JX, Yuan ZP, Wu YM, Zhai SW, Ye HW. Effect of level of metabolizable protein on milk production and nitrogen utilization in lactating dairy cows. J Dairy Sci. 2007;90(6):2960-5. http://dx.doi.org/10.3168/jds.2006-129. PMid:17517736.

Financial Support: FAPESP (Fundação de Amparo à Pesquisa do Estado de São Paulo) - Proc. 2014/20877-7 and 2012-13992-9. 


\section{Abbreviations}

CP, crude protein; DM, dry matter; RDP, rumen-degradable protein; DMI, dry matter intake; MY, milk yield; NDF, neutral detergent fiber; ADF, acid detergent fiber; FCM, fat corrected milk; NH3-N, ammoniacal nitrogen; SCFA, short-chain fatty acids. 